\title{
VERSIONES TRANSGRESORAS Y POLÉMICAS DE BLANCANIEVES: DE ROBERT WALSER A JOÃO CÉSAR MONTEIRO
}

\author{
SNOW WHITE TRANSGRESSIVE, POLEMICAL VERSIONS: \\ FROM ROBERT WALSER TO JOÃO CÉSAR MONTEIRO
}

\author{
Angélica GARCÍA-MANSO \\ Universidad de Extremadura \\ angmanso@unex.es
}

Resumen: Este artículo analiza dos versiones heterodoxas del cuento de hadas Blancanieves: de un lado, la obra de teatro homónima escrita en 1901 por el suizo Robert Walser; y de otro, la película dirigida en el año 2000 por el cineasta portugués João César Monteiro. Desde los parámetros de la relación entre la Literatura y las demás Artes (especialmente con el cine) se obtienen claves semánticas e iconográficas que permiten interpretar el relato popular desde la mitología clásica así como desde el mito de la femme fatale acuñado en el siglo XIX.

Palabras clave: Blancanieves. Robert Walser. João César Monteiro. Mujer fatal.

Abstract: This article analyses two heterodox versions of the fairy tale Snow White: on the one hand, the homonymous play written in 1901 by the Swiss Robert Walser; on the other hand, the film directed by the Portuguese filmmaker João César Monteiro in 2000. From the parameters of the relationship between Literature and other Arts (especially with Cinema) we obtain semantic, iconographic keys that allow us to interpret the popular story from a classical mythology perspective as well as from the femme fatale archetype coined in the 19th century.

Key Words: Snow White. Robert Walser. João César Monteiro. Femme fatale. 


\section{1. ÉRASE UNA VEZ... A MODO DE INTRODUCCIÓN}

Desde que Jacob y Wilhelm Grimm lo publicaran en su colección de Cuentos de la infancia y del hogar (1812-1815) ${ }^{1}$, el relato de la dulce niña de pelo negro como el ébano, piel blanca como la nieve y labios rojos como la sangre, se introdujo con notable fuerza en el imaginario de la cultura occidental.

En efecto, Blancanieves ha sido objeto de múltiples adaptaciones y versiones. Tal vez los primeros fascinados por este cuento de hadas fueran los pintores prerrafaelitas, que con sus virtuosos pinceles comenzaron a dar forma a la prosopografía de esta doncella. Pero habría que esperar al siglo XX, con el alumbramiento del Séptimo Arte, para asistir a la eclosión de este personaje literario como icono visual.

Las adaptaciones cinematográficas de Blancanieves se inician en el cine mudo, con la película francesa La petite Blanche-Neige (1910), producida por la parisina Pathé-Frères (Ramge, 2013: 300), y la norteamericana Snow White (1916), dirigida por J. Searle Dawley y con guion de Winthrop Ames, cuya versión del cuento fue la primera obra teatral producida en Estados Unidos destinada especialmente al público infantil. Dos décadas más tarde, en 1937, Walt Disney acuñaba la iconografía de la hermosa joven que más ha calado en el acervo colectivo (Sánchez Hernández, 2014), y lo hacía en el que habría de ser el primer largometraje de animación de la Historia del Cine²: Blancanieves y los siete enanitos (SnowWhite and the Seven Dwarfs). Desde entonces se han sucedido numerosas y variopintas versiones, de carácter cómico, erótico o específicas para televisión (Zipes, 2011: 115-133). Curiosamente, el cuento experimentó un llamativo auge en 2012, año en el que prácticamente coincidieron en cartelera tres filmes cuyo guion estaba basado en el relato de los Hermanos Grimm: Mirror Mirror, comedia de Tarsem Singh protagonizada por Julia Roberts; Blancanieves y la leyenda del cazador (Snow White \& the Huntsman), de Rupert Sanders, con un reparto estelar encabezado por Charlize Theron y Kristen Stewart; y la española Blancanieves, en la que Pablo Berger imita la narración del cine silente, con fotografía en blanco y negro, y la música como elemento conductor.

Según se desprende de lo hasta aquí expuesto, las sucesivas recreaciones de Blancanieves y su consiguiente pervivencia en el imaginario cultural conforman un hecho poliédrico. $Y$ es precisamente aquí, en este carácter multifocal del que empezó siendo un cuento para niños, donde se inserta el objetivo de las páginas que siguen a continuación.

1 Representa el cuento número 53 de esta colección y corresponde al tipo 709 de la clasificación de AarneThompson.

2 Si bien stricto sensu tal mérito había correspondido en la época del cine mudo a la película El apóstol (1917), del argentino Quirino Cristiani. 


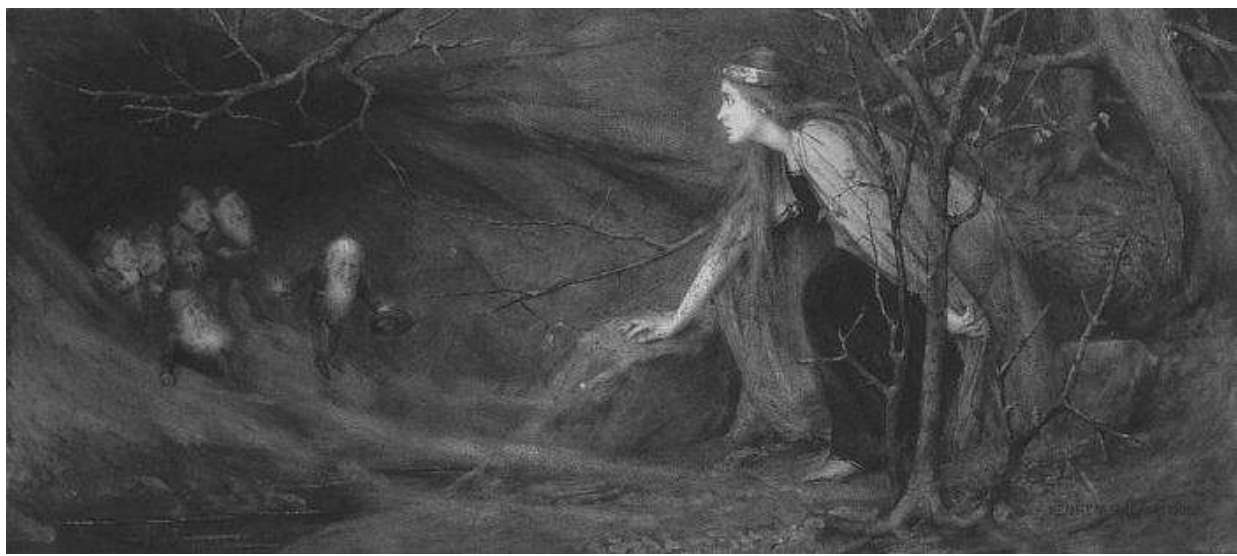

Fig. 1.- Once upon a time (1908), de Henry Meynell Rheam.

Así pues, el texto que el lector tiene entre sus manos se ocupa, tal y como reza su título, de dos versiones transgresoras y polémicas de Blancanieves: la primera de ellas, la pieza de teatro Schneewittchen (1901), en la que el escritor suizo Robert Walser desarrolla una sorprendente continuación del cuento; la segunda, la película Branca de Neve (2000), dirigida por el cineasta luso João César Monteiro a partir del texto de Walser y que constituye el ejercicio fílmico más controvertido de toda la historia del cine portugués, según se tendrá ocasión de argumentar.

Dado que nuestro planteamiento parte, pues, de la relación Literatura / Cine (en un doble nivel, ya que la cinta de Monteiro adapta la obra de Walser, y esta a su vez bebe directamente del relato tradicional), arrancaremos con unas breves pinceladas sobre Monteiro y la marcada voluntad literaria que rezuma toda su filmografía.

\section{EL DESCONOCIDO Y RECONOCIDO JOÃO CÉSAR MONTEIRO}

A principios de 2003 fallecía en Lisboa João César Monteiro, un cineasta del que no muchos habían oído hablar en España. Sin embargo, se había consagrado como una de las personalidades más sobresalientes del cine europeo de la década de los años noventa. De hecho, hacía ya algún tiempo que la prestigiosa revista Cahiers du Cinéma venía dedicándole una especial atención, y sus películas se habían convertido en objeto de numerosos ciclos y retrospectivas en filmotecas de todo el continente.

El deslumbramiento por el cine es algo que Monteiro experimenta desde su propia infancia, y tanta es su inclinación hacia esta arte que decide convertirla en su modo de subsistencia. Así, asumiendo en cierta medida el modelo cahierista, se 
inicia como crítico - con un notable interés por una meca cultural y cinematográfica como es París y una temprana entrevista a François Truffaut- para evolucionar paulatinamente a director de cine. Su eclosión como realizador tendrá lugar relativamente tarde, en torno a los cincuenta años, momento a partir del cual rueda la mayor parte de sus películas, con intervalos de tiempo cada vez más cortos y mayor reconocimiento, si bien nunca exento de polémica, hacia su personal y libre poética cinematográfica.

Cualquier recorrido biográfico de João César Monteiro revela dos circunstancias complementarias como son: una formación autodidacta y una vasta cultura. Este autodidactismo fue consecuencia de una determinada coyuntura familiar, la cual le impidió acceder a unos estudios universitarios que probablemente hubiera despreciado. Sus inquietudes personales, la cercanía con los círculos literarios de los años sesenta y la red de relaciones de trabajo y amistad que estableció a lo largo de su vida con figuras de primer nivel cinematográfico, tanto críticos (principalmente el francés Serge Daney y su compatriota João Bénard da Costa) como directores (Paulo Rocha, el matrimonio Straub-Huillet, Otar losseliani, etcétera), desembocaron en la prodigiosa riqueza cultural que rezuman sus filmes, sus textos, sus palabras. Asimismo, la aproximación a la vida y la obra del cineasta luso permite apreciar una especial incidencia de algunas de sus experiencias vitales en temas recurrentes de su filmografía: cierta forma de vida bohemia, la obsesión por la mujer, la actitud laica, la figura materna, el trastorno psíquico y, primordialmente, la omnipresencia del séptimo arte.

\section{LA INTERRELACIÓN LITERATURA / CINE EN LA FILMOGRAFÍA DE MONTEIRO}

La profunda erudición del realizador luso se manifiesta, de forma muy tangible, en las constantes alusiones a la historia de la literatura que recorren su corpus fílmico. Además, este gusto por la utilización de la literatura en el séptimo arte -una de las señas de identidad inconfundibles del cine portugués- había cobrado una especial intensidad en la generación de cineastas posterior al 25 de abril, y Monteiro se preocupó especialmente por subrayar esta tendencia. Se incluye a continuación un breve repaso de los literatos citados por el cineasta en sus películas, con el fin de esbozar el contexto intertextual y comparatista en el que se enmarca la adaptación de la Blancanieves de Walser.

En primer lugar, en la filmografía de João César Monteiro es posible detectar referencias a los grandes autores de la literatura universal: clásicos como Esquilo y Eurípides, Dante, Shakespeare, Molière, Swift, Dostoievsky, Tolstoi, Lewis Carroll, 
James Joyce o Franz Kafka, entre otros. El director demuestra, asimismo, un notable interés por los escritos de algunos filósofos como Séneca, Spinoza, Rousseau, Diderot y Nietzsche.

No obstante, es a la literatura francesa a la que mayor atención dedica en su cine: Montaigne, La Fontaine, Racine, el Marqués de Sade, Baudelaire, Mallarmé, Verlaine, Rimbaud, Marcel Proust, Apollinaire, Louis-Ferdinand Céline, André Breton, Bataille, Emmanuel Bove, Francis Ponge, Henri Michaux, etcétera.

La literatura portuguesa, como no podía ser de otra forma, goza también de una notable presencia en los filmes monteirianos: la lírica renacentista del gran Camões y los sermones barrocos del Padre António Vieira; las composiciones de poetas adscritos a distintas corrientes del siglo XIX, como Guerra Junqueiro, Cesário Verde, Camilo Pessanha, António Nobre y Teixeira de Pascoaes; conocía profundamente el modernismo portugués, sobre todo a Pessoa y a Sá-Carneiro, a partir de cuya obra, La confesión de Lucio, se planteó hacer una película; también mostró una clara predilección por los surrealistas lusos, especialmente por Mário Cesariny de Vasconcelos, sobre quien le hubiera gustado rodar un documental en la línea del que había filmado acerca de la también poetisa Sophia de Mello Breyner Andresen; finalmente, João César heredó de su padre un gran interés por el escritor del Romantismo Camilo Castelo Branco, con el que compartía numerosas analogías: el origen bastardo, la actitud antisocial, la tendencia a crearse enemigos, el deseo de libertad en una sociedad opresiva y un temperamento anarquista con tendencia a la herejía.

Hay, en fin, otra serie de literatos europeos cuya obra es consustancial a la filmografía de Monteiro: se trata, principalmente, de Hölderlin, Strindberg, Pasolini y Robert Walser, del que pasaremos a ocuparnos detenidamente en breve. En lo que se refiere a la literatura española, destacan Francisco de Quevedo y Federico García Lorca.

Lo expuesto hasta aquí constituye tan sólo una mera nómina de los influjos literarios que salpican por doquier los guiones, tramas y diálogos del cine de João César Monteiro. Sin embargo, todavía hoy queda pendiente un estudio sistematizado y exhaustivo de las adaptaciones de textos literarios (Sánchez Noriega,

3 Sophia de Mello Breyner Andresen (1919-2004), de ascendencia danesa, ha sido una de las figuras más destacadas de la literatura portuguesa del siglo XX. Aunque educada en círculos aristocráticos y en los valores tradicionales de la moral cristiana, se convirtió en uno de los baluartes más significativos de una actitud política liberal. Aparte de como poetisa, se distinguió también como narradora de cuentos y autora de libros infantiles. Ejerció, además, como traductora de Dante Alighieri y de Shakespeare. En 1964 recibió el Gran Premio de Poesía de la Sociedad Portuguesa de Escritores por su obra Livro Sexto. Asimismo, fue distinguida con el Premio Camões en 1999-con lo que pasó a ser la primera mujer portuguesa que recibía el más importante galardón literario de la lengua lusa-y con el Premio Reina Sofía en 2003. 
2000; Pérez Bowie, 2003 y 2004) que en él se produce, el cual, por razones obvias, escapa al alcance de las presentes páginas. Sin lugar a dudas, un análisis de estas características arrojaría nuevos y esclarecedores datos sobre la filmografía de este director portugués.

\section{SCHNEEWITCHEN (1901), LA OBRA TEATRAL DE ROBERT WALSER}

El suizo Robert Walser, nacido en 1878 y autor de novelas de cierto prestigio como Los hermanos Tanner, El ayudante y Jakob von Gunten, ingresó en 1929 en el sanatorio mental de Waldau de forma voluntaria, tras sufrir trastornos nerviosos, alucinaciones auditivas y episodios de agresividad (Palacios, 2006: 153). Cuatro años más tarde fue transferido al asilo de Herisau, donde permanecería internado durante veintitrés años, hasta su muerte, acaecida el 25 de diciembre de 1956, cuando un ataque cardíaco le sorprendió en uno de sus frecuentes y solitarios paseos por las inmediaciones de dicho sanatorio (Iriondo, 2010: 74-76). Su cadáver fue encontrado semienterrado por la nieve.

A los veinte años comenzó a publicar poemas y pequeños textos teatrales -había intentado trabajar en las tablas sin éxito- como Blancanieves, que vio la luz en 1902 dentro de la revista Die Insel y más tarde sería incluida en una selección de poemas titulada Gedichte, editada por Bruno Cassirer en 1909. En este poema dramatizado Walser plantea una inesperada segunda parte del cuento, pero que goza de plena coherencia si se tiene en cuenta el final abierto y un tanto inquietante de algunas versiones populares: tras su matrimonio, Blancanieves y el Príncipe son informados de que la vieja que había intentado asesinar a la protagonista estaba merodeando por el reino. Asustado, el Príncipe y sus sirvientes inician una búsqueda para dar captura a la pérfida anciana. Pero la única persona desconocida que encuentran es a una reina muy hermosa de un reino vecino. Incrédulo de que tal mujer fuera la que había envenenado a Blancanieves, el Príncipe la invita a sus dominios.

El relato se inicia, pues, in medias res, en el punto que quedaba concluido el cuento infantil de los hermanos Grimm y el largometraje de dibujos animados de Walt Disney que en él se inspira. Blancanieves reprocha a su madrastra sus intentos de homicidio con respecto a ella y no acepta las disculpas de la reina. Asimismo, echa en cara al cazador que se dejara convencer, mediante las artimañas de seducción de la madrastra, para perpetrar su asesinato. Más tarde, el príncipe confiesa a Blancanieves que en realidad es a la reina a quien ama, y se arrepiente de no haber dejado a

4 Posiblemente las versiones que plantean este desenlace sean previas al texto de Jacob y Wilhelm Grimm, en el que la madrastra es condenada a morir bailando con unos zapatos incandescentes. 
la primera sumida en su sueño de muerte dentro del cajón de cristal. Contra todo pronóstico, la protagonista pide disculpas a la madrastra por las acusaciones que ha vertido sobre ella, al tiempo que la reina admite que fue la envidia que sentía hacia su belleza lo que la empujó a planear este crimen. Tiene lugar la confesión de amor de la reina al príncipe, quien se entrega a ella. Blancanieves ordena al cazador que lleve a cabo una representación de cómo habría cometido su asesinato. Expresa a continuación su deseo de regresar al bosque con los enanitos y vuelve a reprochar a su madrastra el indigno comportamiento que ha demostrado. El cazador interviene para señalar que el cuento mintió, puesto que la Reina realmente no envidiaba la belleza de Blancanieves. Esta lo acepta y añade que la manzana tampoco estaba envenenada. Tras el beso filial entre ambas mujeres, en los últimos minutos de la cinta interviene el rey, el padre de Blancanieves, personaje que realmente no había fallecido.

Como puede comprobarse, la pieza teatral de Robert Walser incluye elementos sumamente transgresores con respecto al clásico relato infantil: una reina malvada que pide disculpas a su hijastra; un príncipe arrepentido de haber escogido a Blancanieves, cuando en realidad a quien desea es a la madrastra de ésta, quien además le corresponde; una manzana sin veneno, lo cual hace tambalearse uno de los pilares que asocian iconográficamente este fruto a la perversidad femenina (junto a la manzana bíblica de Eva y la que es atributo de la diosa Venus); y, en último lugar, la licencia más Ilamativa de todas, representada por el hecho de que el rey esté vivo, con los numerosos interrogantes que ello lleva asociado.

Según señala Pilar Carrera, esta obra del poeta suizo "irrumpe en una escritura que pone en duda continuamente su congruencia como fábula" (Carrera, 2004: 36) y añade que "Walser nunca hizo de su Blancanieves una parodia. Esta puntualización es fundamental" (Carrera, 2004: 48). De gran trascendencia resultan las palabras de Walter Benjamin cuando afirma que "Walser nos dice cómo siguen viviendo los seres de los cuentos" en la que él califica como "una de las obras más profundas de la literatura reciente" (Benjamin, 2010: 333-334).

\section{BRANCA DE NEVE, LA PELÍCULA DE JOÃO CÉSAR MONTEIRO}

Entre el 8 y el 15 de agosto de 1999, el director luso desarrolla una estancia en París con el objetivo de iniciar los preparativos de un nuevo proyecto fílmico: una película basada en La Filosofía en el tocador (La Philosophie dans le boudoir, 1795), del Marqués de Sade. Monteiro recogió los detalles de este viaje en un libro titulado 
Uma semana noutra cidade. Diário parisiense 5 . Sin embargo, este proyecto sobre Sade fue finalmente abandonado por la gran dificultad de producción que conllevaba. En su lugar se decidió a filmar una adaptación de la pieza de teatro Blancanieves, de Robert Walser, cuyo conocimiento había llegado a João César a través de su amigo Serge Daney, el célebre crítico de cine, años atrás.

Branca de Neve (2000) es, posiblemente, la película más polémica de toda la historia del cine portugués, pues se trata de un filme sin imágenes en el que, a excepción de contados fotogramas, la pantalla permanece en negro durante todo el metraje (sólo la banda sonora permite al espectador reconstruir la acción que se desarrolla). Con ello, João César Monteiro extrapolaba al arte cinematográfico la transgresión óptica, visual, que ya acometiera el pintor ruso Kazimir Malevitch en 1919 con su serie de lienzos titulada Blanco sobre blanco ${ }^{6}$. El filme supuso un escándalo mayúsculo en Portugal. Durante semanas, la polémica acaparó la actualidad cinematográfica portuguesa hasta el punto de convertirse en un asunto de interés nacional. Los propios actores del filme (que desconocían que solo se les estaba grabando en sonido), los productores, la crítica y el público arremetieron con acritud contra Monteiro, que se vio obligado a devolver la mitad de las subvenciones que había recibido para el rodaje. En un clima de máxima detracción, tan solo Manoel de Oliveira -durante décadas, el decano de los cineastas portugueses- se atrevió a salir en defensa de su colega.

En este sentido, Benedykt y Ribeiro interpretan que:

Branca de Neve não nos dá a ver o mesmo que a ouvir, pois som e imagem permanecem dissociados. Assim, seja pelo esvaziamento da imagem, ou pelo trabalho de dissociação entre som e imagem, tal obra produz uma ruptura radical, uma outra variação na linguagem cinematográfica, constituindo-se como un novo cinema que resiste. [...] O filme nos leva a adentrarnos numa linha de fuga que desmorona nossa linguagem preexistente e põe a tremer nossas determinações. [...] Desconforto visual, desconforto auditivo: o cineasta portugués em

5 Uma semana noutra cidade. Diário parisiense (título construido, por cierto, sobre el de la película de Vicente Minelli, Dos semanas en otra ciudad -Two Weeks in Another Town, 1962-), constituye un buen testimonio del dominio de las letras hispanas por parte del cineasta: así, cita a Don Quijote, Campos de Castilla de Antonio Machado, unos versos del personaje Don Carpio de Lope de Vega y la Oceanografía del Tedio, de Eugenio D'Ors.

6 Desde la perspectiva de la historia del cine, cabe señalar que, de forma semejante, la banda sonora de la película Blue (1993), de Derek Jarman, transcurre sobre un fondo monócromo en azul. 
momento algum nos permite um lugar de fácil contemplação (2015: 2324).

También Cantalozella y Negre abundan en esta percepción al afirmar lo siguiente:

La adaptación del texto por parte de Monteiro fue concebida como una acción radical que acabó transformándose en una experiencia que va más allá de lo puramente cinematográfico, ofreciendo un resultado sin equivalentes en el mundo del cine. Una acción fílmica que parte de la negación de proyectar imágenes, es decir, de iluminar la pantalla, y que expone un texto que reconcilia a unos personajes antagónicos [...] La decisión drástica de eliminar la imagen, parte, sin duda, de una serie de reflexiones estéticas radicales en torno a qué es y cómo se debe abordar la adaptación de una obra literaria al cine (2013: 219-220).

El inesperado giro que experimenta la historia de Blancanieves en la película de Monteiro, la peculiaridad de su banda visual y el escándalo sin precedentes que ello trajo consigo contribuyeron a dejar relegado el que, posiblemente, sea el tema, la cuestión capital de Branca de Neve. Se trata del porqué de la elección por parte del director de un texto de Robert Walser como punto de partida para su guion cinematográfico.

A través de Walser, cuya personalidad aparece tan estrechamente vinculada a la institución psiquiátrica, el director portugués prolonga el tema de la locura, clave en su filmografía precedente, a Branca de Neve (la serie de fotografías del literato yaciendo muerto sobre la nieve al principio del metraje, del todo innecesarias para el planteamiento y desarrollo narrativos, no son en absoluto casuales desde esta perspectiva). De hecho, la dilatada reclusión del personaje de João de Deus en un psiquiátrico a lo largo de toda la denominada "Tetralogía de Dios" puede encontrar una de sus fuentes de inspiración en la biografía de Robert Walser, solo que sustituyendo la creación literaria (el escritor suizo continuó componiendo y

7 Conjunto de cuatro películas protagonizadas por "João de Deus", uno de los alter ego de Monteiro. João de Deus padece un desequilibrio mental crónico que lo obliga a permanecer internado en un hospital psiquiátrico. Desde su celda, y como vía de evasión de su aislamiento en el sanatorio, el personaje crea una existencia paralela, mas imaginaria, en la que las vivencias se construyen en función de múltiples y variados referentes cinematográficos. Así pues, la tetralogía constituye el relato de un paciente ingresado en un manicomio, y cada uno de los cuatro largometrajes que integran dicho ciclo representan diferentes episodios de esa vida ficticia y cinematográfica elaborada por la trastornada mente del protagonista. Si bien se trata de filmes autónomos, la consideración del conjunto permite llevar a cabo un seguimiento biográfico, cronológico y espacial del personaje que confiere plena coherencia a la sucesión. 
publicando durante su estancia en ambos manicomios) por la cinematográfica (João de Deus construye una existencia ficticia mediante referentes fílmicos).

La trascendencia de Branca de Neve en el conjunto fílmico de João César Monteiro no radica, pues, en qué texto adapta ni en cómo lo hace, sino en la importancia que en ella adquiere la figura de Walser y sus circunstancias biográficas. De ahí que el desarrollo de la trama pueda permanecer en negro, y no así las fotografías del difunto.

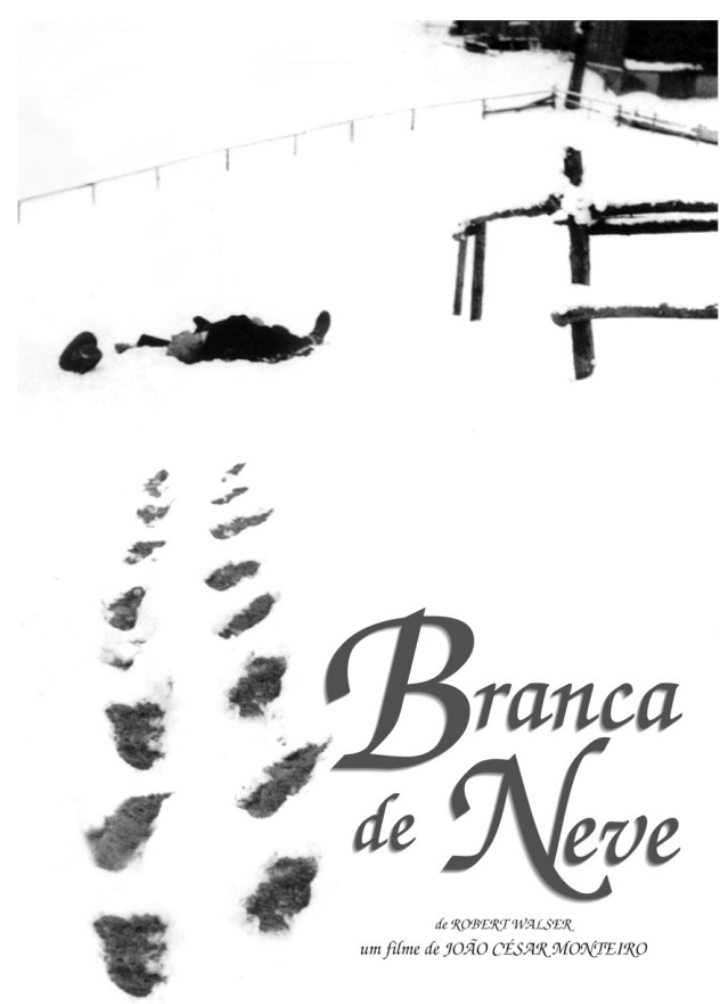

Fig. 2.- Cartel de la película de João César Monteiro, a partir de las fotografías de Robert Walser en las que yace muerto en la nieve. El diseño del póster reproduce cromáticamente (nieve-sangre-ébano) la descripción física de Blancanieves.

\section{CONCLUSIÓN}

Las películas basadas en cuentos no solo constituyen un excelente recurso didáctico para niños de distintos niveles de Educación Primaria (Martín Vegas, 2009: 401), sino que pueden estar destinados también al público adulto. Así lo demuestran una serie de filmes cuyo valor estético y recepción crítica los han convertido en clásicos de la 
historia del cine: La bella y la bestia (La belle et la bête, 1946), de Jean Cocteau; Lady Halcón (Ladyhawke, 1984), de Richard Donner, o Eduardo Manostijeras (Edward ScissorHands, 1990), de Tim Burton, son tan solo un botón de muestra de esta circunstancia.

La intertextualidad es, en su origen, un concepto filológico que puede definirse, en términos muy generales, como "la presencia de un texto en otro texto". Cuando este concepto se extrapola desde la literatura a las demás artes surge el denominado "arte comparado", que designa las relaciones que mantienen entre sí las distintas manifestaciones artísticas (Frenzy Remak, 1956:67-71). Los tentáculos del arte comparado han terminado por alcanzar también al séptimo arte, de forma que en las últimas décadas se ha introducido con gran fuerza en el panorama investigador y bibliográfico la reflexión a propósito del cine y su relación con las demás artes (lampolsky, 1996). La filmografía de João César Monteiro, abundante en referencias literarias, constituye un nítido ejemplo de esta interrelación que el cine establece y mantiene con las demás artes, de forma que la investigación de la obra de este director portugués puede ser enfocada desde los presupuestos de la intertextualidad y la literatura comparada. Así sucede con su película Branca de Neve, en la que se produce una relación cine / literatura de doble calado: la adaptación de la pieza teatral de Robert Walser, en primer término, y la revisión del personaje como tema de fondo (Rábade Villar, 2005).

A lo largo de las páginas precedentes se han abordado dos versiones que reelaboran notablemente el arquetipo acuñado por los Hermanos Grimm en 1812. La primera de ellas, un texto de juventud de Walser, aniquila la versión tradicional del cuento y transgrede prácticamente todos sus elementos, incluida la supervivencia del padre de la protagonista. La segunda, la adaptación cinematográfica de Monteiro, es la película que mayor polémica ha generado en el devenir del séptimo arte portugués, al tratarse de un filme sin imágenes en el que la pantalla permanece en negro durante todo el metraje. No obstante, cabe hacer hincapié en el hecho de que para el cineasta lo importante no es la obra de Walser que adapta, sino el recurso a este literato. Para Monteiro, introducir a Robert Walser en su obra significa seguir reflexionando sobre el tema central en torno al que gira todo su cine (la locura) y enfrentarse a la acusación que lo persiguió toda su vida: la de estar loco.

A fin de cuentas, el texto de Walser $-y$, por consiguiente, los diálogos del filme de Monteiro- pone el dedo en la llaga en los ingredientes psicoanalíticos en los que reside la universalidad de Blancanieves: esa amalgama de pasiones femeninas en la que concurren la competitividad y la envidia por poseer la belleza y la juventud, es decir, la condición de ser deseable y deseada por los hombres (Roura, 1996), y que se remonta al mito clásico que vincula a Afrodita, la diosa del amor y la belleza, con Psique, la joven mortal de inconmensurable hermosura destinada a ser la esposa de su hijo (Grimal, 1981: 458b-459b). Por ello, la presencia de la manzana en Blancanieves adquiere una 
importancia simbólica de gran trascendencia: es el icono que convierte a la malvada madrastra en una prolongación de la Eva bíblica (la portadora del fruto prohibido) y de la Venus pagana (receptora de la manzana de oro que desata la Guerra de Troya) y, por tanto, en una de las encarnaciones más tempranas del mito de la "mujer fatal" o femme fatale (Bornay, 1990) que tanta fortuna habría de cosechar en el imaginario del siglo XIX (Eetessam, 2009), época en la que los Grimm dieron forma a su relato.

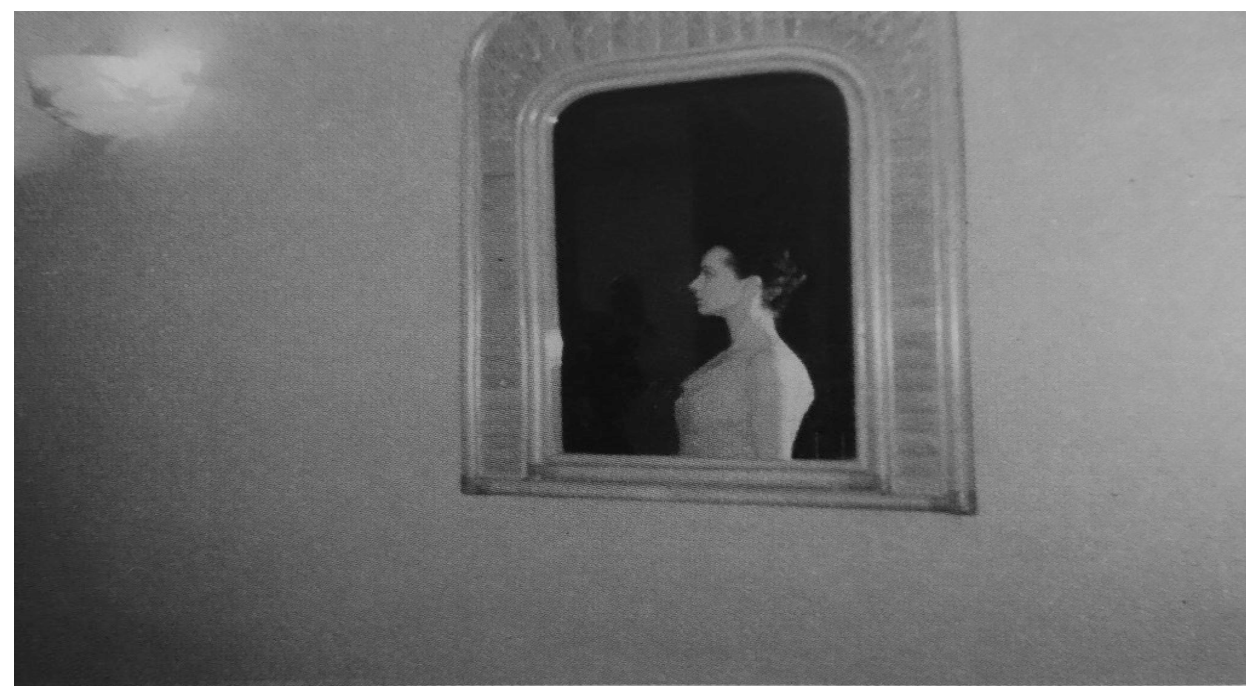

Fig 3.- Muriel Sovay, actriz prevista para interpretar el papel de la reina en Branca de Neve. Fotografía de João César Monteiro.

Sea como fuere, la red de conexiones que se establece entre los cuentos, la mitología clásica y los llamados mitos de la contemporaneidad (Gubern, 2002: 58) es tan compleja como sorprendente. De hecho, la manzana envenenada sirve de gozne entre la pérfida reina de Blancanieves y otra bruja de artes demoníacas como es el hada vieja o hada mala de La bella durmiente. $Y$ es que este personaje, conocido universalmente como Maléfica a partir del filme de animación de Disney de 1959, no es más que un trasunto de la diosa Eris, quien ofendida por no haber sido invitada a las bodas de Tetis y Peleo (de igual manera que Maléfica se siente indignada por no haber sido convocada a los festejos en honor del nacimiento de la princesa Aurora), arroja la manzana de la discordia en mitad del banquete de los dioses. Al fin y al cabo, la de hechicera es una de las facetas más abordadas en el tratamiento decimonónico de la mujer fatal, como bien demuestran los numerosos lienzos prerrafaelitas dedicados, por ejemplo, a Circe ${ }^{8}$.

8 Sobresale en este sentido la tríada pintada por John William Waterhouse: Circe offering the cup to Ulisses (1891), Circe Invidiosa (1892) y The Sorceress (c. 1911). 
Los cuentos populares poseen, pues, un sustrato infinito de significados. La heterodoxia adoptada por Walser y Monteiro a la hora de versionar Blancanieves surge de distanciarse de la lectura superficial y apostar por plasmar, uno en versos y otro en imágenes (o sin ellas, mejor dicho) ${ }^{9}$ la sugerente lectura entre líneas que destila este clásico sobre la condición femenina en el que se opone la mujer cándida y angelical a la femme fatale ${ }^{10}$.

\section{REFERENCIAS BIBLIOGRÁFICAS}

BENEDYKT, B. I. y RIBEIRO, C. R. (2015).“Pensar e resistir com o cinema: interpelacões deleuzianas ao campo educacional". Revista Sul-Americana de Filosofia e Educação 23, 13-31.

BENJAMIN, W. (2010). Obra completa. Libro II/vol. 1. Madrid: Abada.

BORNAY, E. (1990). Las hijas de Lilith. Madrid: Cátedra.

CANTALOZELLA, J. y NEGRE, M. (2013). “Las Voces y el Cine Invisible”. BRAC - Barcelona Research Art Creation 1.2, 203-227.

CARRERA, P. (2004). Walter Benjamin: el paseante y la ciudad. Tesis Doctoral inédita. Madrid: Universidad del País Vasco.

EETESSAM PÁRRAGA, G. (2009). “Lilith en el arte decimonónico: estudio del mito de la femme fatale". Signa: Revista de la Asociación Española de Semiótica 18, 229-249 (también en http:// www.cervantesvirtual.com/obra/lilith-en-el-arte-decimonnico-estudio-del-mito-de-lafemme-fatale-0/[02/03/2016]).

FRENZ, H. y REMAK, H.H.H. (1956). "Teaching the Comparative Arts. A Challenge”. College English 18, 67-71.

GRIMAL, P. (1981). Diccionario de mitología griega y romana. Barcelona: Paidós.

GUBERN, R. (2002). Máscaras de la ficción. Barcelona: Anagrama.

IAMPOLSKY, M. (1996). La teoría de la intertextualidad y el cine. Valencia: Episteme.

IRIONDO ARANGUREN, M. (2010). "El paseo y la concepción del paisaje en Robert Walser".

Enrahonar: Quaderns de Filosofía 45, 69-84.

MARTÍN VEGAS, R. A. (2009). Manual de didáctica de la lengua y la literatura. Madrid: Síntesis.

MONTEIRO, J. C. (1999). Uma semana noutra cidade. Diário Parisiense. Lisboa: \& etc.

9 Curiosamente, dos de las escasas fotografías de rodaje conservadas (Nicolau, 2005) son las que permiten comprobar la relación de la película de João César Monteiro con el mito de la mujer fatal, a través de la caracterización física (vestuario, maquillaje, peinado) de Blancanieves y de su madrastra, que denotan y connotan la pureza e inocencia de la primera, así como el reclamo sexual y la perfidia de la segunda.

10 Parece oportuno recordar a este respecto el cortometraje de animación Betty Boop: Snow White (Dave Fleischer, 1933), en el que estos dos arquetipos se dan la vuelta y es Blancanieves quien asume el papel de mujer fatal por esa condición de chica flapper y de abierta sexualidad que destila Betty. Además, se trata de una de las primeras adaptaciones animadas de Blancanieves y, como tal, habría de influir en la versión posterior de Walt Disney. 
NICOLAU, J. (2005). João César Monteiro. Lisboa: Cinemateca Portuguesa.

PALACIOS CRUZ, V. H. (2006). “Caminando con Robert Walser hacia el no-lugar de su literatura”. Humanidades: Revista de la Universidad de Montevideo 6.I, 147-172.

PÉREZ BOWIE, J. A. (2003). “La teoría de la adaptación cinematográfica de textos literarios.

Estado de la cuestión". En La adaptación cinematográfica de textos literarios. Teoría y práctica, J. A. Pérez Bowie, 11-30. Salamanca: Plaza Universitaria Ediciones. (2004). “La adaptación cinematográfica a la luz de algunas aportaciones teóricas recientes".

Signa: Revista de la Asociación Española de Semiótica 13, 277-300.

RÁBADE VILLAR, M. C. (2005). As terceiras mulleres. Vigo: Galaxia.

RAMGE, R. (2013). Das Dokument des Grauens. Eine Chronik des Horrorfilms. Band 1: Die Wiege des Schreckens. Belp: Freshpics Studios Ramge.

ROURA, A. (1996). La mujer ante el espejo. Apuntes sobre el amor. Barcelona: Thassalia.

SÁNCHEZ HERNÁNDEZ, T. (2014). “De los Grimm a Disney. Un estudio narratológico de la adaptación de Blancanieves". Con A de animación 4, 110-125.

SÁNCHEZ NORIEGA, J. L. (2000). De la literatura al cine. Teoría y análisis de la adaptación.

Barcelona: Paidós.

WALSER, R. (1909). Gedichte. Berlin: Verlag Bruno Cassirer.

(1997). Poemas-Blancanieves. Barcelona: Icaria Editorial.

ZIPES, J. (2011). “Cracking the Magic Mirror: Representations of Snow White". En The Enchanted Screen: The Unknown History of Fairy-Tale Films, J. Zipes, 115-133. New York: Routledge.

Recibido el 21 de febrero de 2016.

Aceptado el 4 de noviembre de 2016. 